\title{
The leaf aqueous extract of Myrianthus arboreus P. Beauv. (Cecropiaceae) improved letrozole-induced polycystic ovarian syndrome associated conditions and infertility in female Wistar rats
}

\author{
Marie Alfrede Mvondo ${ }^{1 *}$, Flavie Ingrid Mzemdem Tsoplfack', Charline Florence Awounfack ${ }^{2}$ and
}

Dieudonné Njamen²

\begin{abstract}
Background: Myrianthus arboreus P. Beauv. (Cecropiaceae) is a medicinal plant used to treat female infertility. The aqueous extract of $M$. arboreus leaves was found to improve the fertility of healthy female Wistar rats. In the present study, we proposed evaluating the effects of such an extract on an animal model of infertility caused by polycystic ovary syndrome (PCOS), in order to bring scientific evidence to the curative action of this plant against female infertility.

Methods: Following a 21-day administration (gavage) of letrozole (1 mg/kg), animals with PCOS, indicated by overweight and an estrous cycle blocked in the diestrus phase, were co-treated with letrozole $(1 \mathrm{mg} / \mathrm{kg})$ and the aqueous extract of M. arboreus leaves at doses of 20, 110 and $200 \mathrm{mg} / \mathrm{kg}$. The positive control received clomiphene citrate $(1 \mathrm{mg} / \mathrm{kg})$ and metformin $(200 \mathrm{mg} / \mathrm{kg})$. The negative control received distilled water. Each group of animals was made up of 10 female rats. Vaginal smear was examined 7 days before and during co-treatments. Co-treatments were orally administered for 30 consecutive days and 5 animals per group were sacrificed thereafter for biochemical and histological analyses. The 5 remaining animals in each group were crossbred with males of proven fertility for 5 consecutive days. The daily examination of vaginal smears allowed evaluating fertility index. Following parturition, gestation rate was calculated.

Results: The aqueous extract of $M$. arboreus leaves reversed letrozole effects by decreasing body weight, abdominal fat accumulation, and serum levels of $\mathrm{LH}$ and testosterone $(p<0.001)$. Ovarian dynamic was improved and the number of tertiary, Graafian follicles $(p<0.001)$ and corpus luteum increased while that of cystic $(p<0.001)$ and atretic follicles $(p<$ $0.01)$ decreased. These effects were associated with increased serum levels of estradiol, decreased ovarian oxidative stress, the resumption of the estrous cycle, the hypertrophy of uterine epithelial cells and increased fertility index and gestation rate.
\end{abstract}

(Continued on next page)

\footnotetext{
*Correspondence: mvondo.mariealfrede@yahoo.com; alfrede.mvondo@univdschang.org

'Research Unit of Animal Physiology and Phytopharmacology, University of Dschang, P.O. Box 67, Dschang, Cameroon

Full list of author information is available at the end of the article
}

(c) The Author(s). 2020 Open Access This article is licensed under a Creative Commons Attribution 4.0 International License, which permits use, sharing, adaptation, distribution and reproduction in any medium or format, as long as you give appropriate credit to the original author(s) and the source, provide a link to the Creative Commons licence, and indicate if changes were made. The images or other third party material in this article are included in the article's Creative Commons. licence, unless indicated otherwise in a credit line to the material. If material is not included in the article's Creative Commons licence and your intended use is not permitted by statutory regulation or exceeds the permitted use, you will need to obtain permission directly from the copyright holder. To view a copy of this licence, visit http://creativecommons.org/licenses/by/4.0/ The Creative Commons Public Domain Dedication waiver (http://creativecommons.org/publicdomain/zero/1.0/) applies to the data made available in this article, unless otherwise stated in a credit line to the data. 
(Continued from previous page)

Conclusions: These results justify at least in part, the traditional use of $M$. arboreus against female infertility and suggest that this plant could be a promising alternative treatment to improve symptoms associated with different PCOS phenotypes.

Keywords: Polycystic ovary syndrome, Female infertility, Myrianthus arboreus, Female Wistar rats

\section{Background}

Polycystic ovary syndrome (PCOS) is one of the most prevalent reproductive endocrinopathies affecting 6-10\% of reproductive-age women [1] and $40 \%$ of them experience infertility [2]. The latter is known as a failure to conceive after 1 year of appropriately timed unprotected intercourse [3]. In women with PCOS, infertility could result from an impaired ovarian folliculogenesis. Indeed, hyperandrogenism, one of the key features of PCOS, is reported to stimulate an excessive secretion of gonadotropin releasing hormone $(\mathrm{GnRH})$ by hypothalamic neurons and luteinizing hormone $(\mathrm{LH})$ by the pituitary gland [4]. Hyperandrogenism is also reported to induce an excessive release of insulin by pancreatic $\beta$-cells [5]. The resulted hyperinsulinemia was found to decrease the hepatic production of insulin-like growth factor (IGF) binding protein-1 and to consequently increase the bioavalability of IGF-1 [6]. Insulin and IGF-1 were found to amplify the effects of LH on granulosa cells, inducing prematurely terminal differentiation [7]. Premature maturation and differentiation of granulosa cells were reported to induce preantral follicular growth arrest, anovulation and cyst formation [7, 8]. All these events could affect fertility in women with PCOS.

Medications like clomiphene citrate, metformin and gonadotropins are commonly used for the treatment of PCOS and PCOS-related infertility. These treatments aimed to increase insulin sensitivity and to improve hyperinsulinemia, hyperandrogenism, ovulatory function and menstrual irregularity $[9,10]$. The prescription of metformin, an insulin sensitizer, in polycystic ovarian disease slightly improves ovulation [11], although the conception rate remains disappointing [11, 12]. It is often associated with clomiphene citrate $(\mathrm{CC})$ for a better yield. CC has been used for over 40 years as a triggering agent for first-line ovulation [13, 14]. The literature reports that the concomitant use of $\mathrm{CC}$ and metformin significantly increases ovulation and pregnancy rates [11, 12, 15]. Gonadotropins are used when oral medications that trigger ovulation fail to induce ovulation in patients with PCOS [14]. Surgical treatment and in vitro fertilization (IVF) are generally practiced to solve the problem of infertility in patients with PCOS wishing to have children and who did not have a favorable outcome with drug treatments $[14,16]$. The use of laparoscopic ovarian drilling (LOD) for instance is considered in women with PCOS resistant to CC. Resistance to CC is evoked in the absence of ovulation or pregnancy following a 6-month treatment [17]. IVF is reserved for women with PCOS who were unable to conceive following treatment with gonadotropins [14].

Although treatments recommended for PCOS effectively relieve symptoms associated with PCOS, they are commonly associated with serious side effects $[14,18,19]$. Moreover, some of them (gonadotropins and surgical interventions) are costly and time-consuming and their use requires intensive monitoring [14], hence the urgency to develop innovative active substances that are better tolerated, more efficient and affordable than the currently applied pharmacological and surgical approaches.

Previous studies reported the efficacy of some plants such as Aleo barbadensis [20], Tephrosia purpurea [21], Wistthania somnifera and Tribulus terrestris [22], Allium fistulosum [23] and Phyllanthus muellerianus [2], in the restoration of insulin sensitivity, hormonal profile and ovarian function in rats with PCOS. These studies suggest that plants with fertilizing and anti-diabetic properties are potential alternatives for the treatment of PCOS. Myrianthus arboreus P. Beauv. (Cecropiaceae) for instance, commonly known as "kogom" in Bassa, "angokong" in Bulu and "lilanka" in Dschang, three Cameroonian vernacular languages, is a tree widely distributed in West, Central and East Africa where its young leaves are used for the treatment of various diseases, including diabetes [24-27]. The leaf aqueous extract of $M$. arboreus is used in Cameroon against amenorrhea, female infertility (primary and secondary) and to improve lactation [24, 28, 29]. Kasangana et al. [29] reported that the root bark extracts of $M$. arboreus exhibits antidiabetic potential in vitro. Additionally, the aqueous extract of $M$. arboreus leaves was found to improve the fertility of healthy female Wistar rats [30]. Although bearing all these properties, $M$. arboreus has not yet been investigated on an animal model of PCOS-related infertility.

In order to test the hypothesis according to which plants with fertilizing and anti-diabetic properties are potential alternatives for the treatment of PCOS, and to bring scientific evidence to the curative action of this plant against female infertility, we investigated the ability of the aqueous extract of $M$. arboreus leaves to relieve PCOS-associated symptoms and to restore the fertility of 
PCOS animals. In this regard, the effects of the aqueous extract of $M$. arboreus leaves were investigated on body weight, estrous cycle, sex hormones, ovarian histomorphology, oxidative stress-related parameters, uterine growth, fertility index and gestation rate.

\section{Methods}

Plant material and preparation of the aqueous extract

Myrianthus arboreus was collected in October 2018 in Santchou (West region, Cameroon). The plant was authenticated by a botanist, Mr. Victor Nana, at the Cameroon National Herbarium where a voucher specimen has been deposited under the number 34045/HNC.

Following collection, fresh and clean leaves of $M$. arboreus were air-dried (under shade), and ground. One kilogram of the resulting powder was macerated in $10 \mathrm{~L}$ of distilled water for $12 \mathrm{~h}$ and then filtered with Whatman paper number 4 . This first filtrate was stored in a refrigerator unttil use. The same amount of distilled water $(10 \mathrm{~L})$ was poured into the residue for an additional maceration of $12 \mathrm{~h}$. Following the filtration of this second macerate, the filtrate obtained was added to the first filtrate. The whole was freeze-dried and a total dry mass of $53.53 \mathrm{~g}$ of the aqueous extract was obtained. This extract was kept at $4{ }^{\circ} \mathrm{C}$ in an airtight container until use.

Three doses (20, 110 and $200 \mathrm{mg} / \mathrm{kg}$ of body weight) of this extract were administered to animals. At these doses, the aqueous extract of $M$. arboreus leaves was reported to stimulate female Wistar rat sexual maturation and to improve the fertility of normocyclic rats, following a 30-day treatment [30]. These doses were extrapolated from the traditional posology against female infertility [31]. The dose of $20 \mathrm{mg} / \mathrm{kg}$ was obtained as the therapeutic dose for young adult women [31]. The animal equivalent dose of $200 \mathrm{mg} / \mathrm{kg}$ was obtained by multiplying $20 \mathrm{mg} / \mathrm{kg}$ by 10 and the dose of $110 \mathrm{mg} / \mathrm{kg}$ represents the mean of these two doses (20 and $200 \mathrm{mg} / \mathrm{kg}$ ) [31].

\section{Animals}

Healthy young female Wistar rats aged 10-12 weeks and weighing $140-160 \mathrm{~g}$ prior to the experiment were obtained from the breeding facility of the Research Unit of Animal Physiology and Phytopharmacology, University of Dschang (Cameroon). They were housed in clean plastic cages at room temperature and lit by natural light. All rats had free access to diet (a standard soy-free rat diet in order to eliminate exposure to exogenous estrogenic compounds) and tap water ad libitum.

\section{Ethical statement}

Animal housing and all experiments were conducted in conformity with the European Union on Animal Care
(CEECouncil 86/609) guidelines adopted by the Institutional Ethics Committee of the Cameroon Ministry of Scientific Research and Technology Innovation (Reg. no. FWA-IRD 0001954).

\section{Study design}

Sixty female Wistar rats were used to evaluate the effects of the aqueous extract of $M$. arboreus leaves on PCOSassociated symptoms and PCOS-related infertility. PCOS was induced with letrozole following the method described by Ndeingang et al. [2] with slight modifications. Briefly, animals were checked for three consecutive normal estrous cycles by vaginal smear examination [2] and divided into 6 groups of 10 animals each. Group 1 served as the normal control and received the vehicle (distilled water; $1 \mathrm{~mL} / 100 \mathrm{~g}$ ). Animals of groups 2-6 were treated with letrozole (LTZ; $1 \mathrm{mg} / \mathrm{kg}$ dissolved in distilled water) for 21 consecutive days for PCOS induction. Seven days before the end of PCOS induction (from day 15 to day 21), vaginal smears were collected from each rat and observed each morning (07:30 a.m. to 08:30 a.m.) to determine their estrous cyclicity, as previously described [2]. At day 22, animals were assigned to the following treatment groups:

NC $(n=10)$ : normal control, healty animals (animals without PCOS) receiving the vehicle (distilled water); LTZ ( $n=10)$ : animals with PCOS receiving letrozole (1 $\mathrm{mg} / \mathrm{kg})$ and the vehicle;

LTZ + CC + MET $(n=10)$ : animals with PCOS treated with letrozole $(1 \mathrm{mg} / \mathrm{kg})$, clomiphene citrate $(1 \mathrm{mg} / \mathrm{kg})$ and metformin $(200 \mathrm{mg} / \mathrm{kg})$;

$\mathrm{LTZ}+\mathrm{AE} 20(\mathrm{n}=10)$ : animals with PCOS treated with letrozole $(1 \mathrm{mg} / \mathrm{kg})$ and the aqueous extract of $M$. arboreus leaves at the dose of $20 \mathrm{mg} / \mathrm{kg}$;

LTZ + AE110 ( $n=10)$ : animals with PCOS treated with letrozole $(1 \mathrm{mg} / \mathrm{kg})$ and the aqueous extract of $M$. arboreus leaves at the dose of $110 \mathrm{mg} / \mathrm{kg}$;

LTZ + AE200 ( $\mathrm{n}=10)$ : animals with PCOS treated with letrozole $(1 \mathrm{mg} / \mathrm{kg})$ and the aqueous extract of $M$. arboreus leaves at the dose of $200 \mathrm{mg} / \mathrm{kg}$.

Treatments were given orally (every morning from 06: 30 a.m. to 07 h30 a.m.) for 30 consecutive days. During this treatment period, the administration of letrozole was not interrupted as the latter is a reversible aromatase inhibitor $[4,22]$. Thus, to maintain the cause of PCOS (aromatase inhibition) in experimental animals, letrozole was co-administered with the aqueous extract of $M$. arboreus leaves during the treatment period to determine whether or not the aforementioned extract could improve PCOS symptoms despite the presence of the causal element. The vaginal smear of each rat continued to be examined microscopically from the 
beginning to the end of treatments. The stages of the estrous cycle were determined by identifying the types of cells present in rat vaginal smears [32]: leucocytes (diestrus); nucleated epithelial cells (proestrus); cornified cells (estrus); and mixed cells (nucleated, cornified, leucocytes) (metestrus). The appearance of these cells depends on the histological changes that the vaginal epithelium undergoes in relation to the hormonal (estradiol) fluctuations occurring at the different stages of the estrous cycle [33, 34]. In addition, our previous studies showed that in animals confined in the same group for several days, the estrous cycles are synchronized and this was evidenced by the appearance of identical histological changes of the vaginal epithelium within the same group $[35,36]$. Therefore, results on the estrous cycle in this study, show the most represented phase of the estrous cycle in each group.

At the end of the 30-day treatment, 5 animals in each group were allowed to fast for $12 \mathrm{~h}$ and were anesthesized thereafter using an intraperitoneal injection of diazepam $(10 \mathrm{mg} / \mathrm{kg})$ and ketamine $(50 \mathrm{mg} / \mathrm{kg})$. Following anesthesia, animals were sacrificed by incision of the abdominal artery. Blood was collected from each rat in dry tubes (without an anticoagulant) using a catheter inserted into the aforementioned artery. Blood flowed into dry tubes until death of animals indicated by cessation of breathing and heartbeat. The tubes were kept at room temperature and serum was separated by centrifugation at $3000 \mathrm{rpm}$ for $15 \mathrm{~min}$. The resulting serum was stored at $-20^{\circ} \mathrm{C}$ until use. Abdominal fat of each rat were collected and weighed. Ovaries and uteri were collected, cleaned of fat, weighed (only the uterus) and fixed (the whole uterus and the left ovary) in 10\% formalin for histological analysis. The right ovary was homogenated in $0.9 \% \quad \mathrm{NaCl}(0.1 \mathrm{~g}$ per $1 \mathrm{~mL})$. Tissue homogenates were centrifuged at $3000 \mathrm{rpm}$ for $15 \mathrm{~min}$. The resulting supernatants were stored at $-20^{\circ} \mathrm{C}$ until use. Animal body weight was recorded weekly from the beginning to the end of the study.

The remaining female rats in each group (5/group) were crossbred with vigorous males of proven fertility (one male for two females) for 5 consecutive days, duration of an estrous cycle. The vaginal smear was examined daily (07:30 a.m. to 08:30 a.m.) to check the presence of spermatozoa (indicator of gestation) [30]. At the sight of these, female rats were separated from males and this day was considered the first day of gestation [30] and pregnant rats were followed up until parturition. At the end of the study, fertility index and gestational rate were calculated as follows: fertility index $=$ (number of pregnant $/$ number of mated $) \times 100$; gestation rate $=($ number of females with viable fetuses at birth/total number of gestational females) $\times 100[30]$.

\section{Biochemical analyses}

Serum levels of estradiol, testosterone and luteinizing hormone (LH) were assessed by ELISA tests using reagent kits purchased from Calbiotech (El Cajon, California, USA). Analytical sensitivity for each kit was $5 \mathrm{mIU} /$ $\mathrm{ml}$ for $\mathrm{LH}, 20 \mathrm{ng} / \mathrm{ml}$ for estradiol and $0.2 \mathrm{ng} / \mathrm{ml}$ for testosterone. The standard curve range was $5-200 \mathrm{mIU} / \mathrm{ml}$ for $\mathrm{LH}, 20-3000 \mathrm{ng} / \mathrm{ml}$ for estradiol and $0.2-18 \mathrm{ng} / \mathrm{ml}$ for testosterone. The absorbance of calibrators and specimen was determined using an ELISA microplate reader, the Multiskan ascent plate reader, purchased from MTX Lab Systems, Inc. (Brandenton, USA). The concentration was evaluated by means of a calibration curve established from the calibrators supplied with the kits.

Ovarian levels of malondialdehyde (MDA) were determined by the method of Wilbur et al. [37] which is based on the reaction with thiobarbituric acid (TBA) at $90-100{ }^{\circ} \mathrm{C}$. In the TBA test reaction, MDA or MDA-like substances and TBA react with the production of a pink pigment having an absorption maximum at $532 \mathrm{~nm}$. Tissue level of MDA was determined using the following formula: $[\mathrm{MDA}]=\mathrm{DO} / \varepsilon .1 . \mathrm{m}$, where $[\mathrm{MDA}]=$ concentration of MDA ( $\mathrm{nM} / \mathrm{mg}$ of tissue); $\mathrm{DO}=$ absorbance of the sample - absorbance of the reagent blank; $\varepsilon=$ molar extinction coefficient $\left(1.56 .10^{-4} \mathrm{nM}^{-1} \mathrm{~cm}^{-1}\right) ; \mathrm{l}=$ path length $(1 \mathrm{~cm}) ; \mathrm{m}=$ mass of the tissue collected for homogenization (mg).

Ovarian levels of total proteins were assessed using a reagent kit purchased from Randox (London, UK), following the manufacturer's instructions. This parameter was used to assess tissue levels of antioxidant enzymes (catalase, total peroxidases) as the amount of each of these enzymes in tissue (ovaries) homogenates was assessed relative to total protein content in the aforementioned tissue.

Catalase activity was estimated by the method of Sinha [38] which is based on the decomposition of $\mathrm{H}_{2} \mathrm{O}_{2}$ into water. The concentration of undecomposed $\mathrm{H}_{2} \mathrm{O}_{2}$ was evaluated using a calibration curve established from a standard solution $\left(50 \mathrm{mM} \mathrm{H}_{2} \mathrm{O}_{2}\right)$. Tissue catalase activity was determined as follows: C. $\mathrm{A}=\mathrm{DO} /$ a.t.p, where: $\mathrm{C}$. $\mathrm{A}=$ catalase activity (mole of $\mathrm{H}_{2} \mathrm{O}_{2} / \mathrm{min} / \mathrm{g}$ of total proteins); $\mathrm{DO}=$ absorbance of the sample - absorbance of the reagent blank; $\mathrm{a}=$ slope of the calibration curve; $\mathrm{t}=$ reaction time $(1 \mathrm{~min}) ; \mathrm{p}=$ ovarian total protein level $(\mathrm{g})$.

Ovarian levels of total peroxidases were determined by the method of Habbu et al. [39] and the method description partly reproduces their wording. Briefly, ovarian homogenate $(0.5 \mathrm{ml})$ was taken, and to this were added $1 \mathrm{ml} \mathrm{KI}$ solution $(10 \mathrm{mM})$ and $1 \mathrm{ml}$ sodium acetate $(40$ $\mathrm{mM})$. The absorbance of potassium iodide was read at $353 \mathrm{~nm}$, which indicates the amount of peroxidase. Then $20 \mu \mathrm{l}$ of $\mathrm{H}_{2} \mathrm{O}_{2}(15 \mathrm{mM})$ was added, and the change in 
the absorbance in 5 min was recorded. Units of peroxidase activity were expressed as the amount of enzyme required to change the optical density by 1 unit per min. The specific activity expressed in terms of units per $g$ of proteins was deduced by the law of Beer-Lambert [40] as follows: $\mathrm{C}=\mathrm{DO} / \varepsilon$.l.p, where $\mathrm{C}=$ concentration of ovarian total peroxidases $(\mathrm{mM} / \mathrm{g}$ of total proteins); $\mathrm{DO}=$ optical density; $\varepsilon=$ molar extinction coefficient $\left(11.3 \mathrm{M}^{-1} \mathrm{~cm}^{-1}\right)$; $\mathrm{l}=$ path length $(1 \mathrm{~cm}) ; \mathrm{p}=$ ovarian total protein level $(\mathrm{g})$.

\section{Histological analysis}

Histological analyses of the ovary and the uterus were assessed from $5 \mu \mathrm{m}$ sections of paraffin embedded tissues following hematoxylin-eosin staining. Histomorphological changes were assessed on microphotographs using a Scientico STM-50 microscope equipped with a Celestron MA411101 camera connected to a computer where the image was transferred and analyzed with the Image J1.3 software.

\section{Statistical analysis}

Data were analyzed using the GraphPad Prism 5.03 software and are presented as mean \pm standard error of the mean (S.E.M.), except data of the estrous cycle which rather show the most represented phase of the estrous cycle in each group, as reported by Belani et al. [32]. Statistical significance and the difference among groups were evaluated by one-way analysis of the variance (ANOVA) followed by Tukey test for multiple comparisons. Differences were considered significant at $p<0.05$.

\section{Results}

\section{Body weight and relative abdominal fat weight}

Table 1 shows that animal body weight before PCOS induction was similar in all groups. Following a 21-day administration of letrozole, animal body weight increased by at least $12 \%(p<0.001)$ as compared with the normal control group. The combined administration of clomiphene citrate and metformin reversed the effect of letrozole as it decreased animal body weight by $26 \%(p<$ 0.001 ), as compared with the LTZ group. The aqueous extract of $M$. arboreus leaves induced a similar effect at the dose of $110 \mathrm{mg} / \mathrm{kg}$, as it decreased animal body weight by $17 \%(p<0.001)$ as compared with the LTZ group.

The relative weight of the abdominal fat increased by $41 \%$ in the LTZ group as compared with the normal control group (Table 1). The combined administration of clomiphene citrate and metformin decreased this parameter by $83 \%(p<0.001)$ as compared with the LTZ group. The aqueous extract of $M$. arboreus leaves induced a similar effect at tested doses.

\section{Estrous cycle}

Figure 1a shows that the estrous cycle of animals in the normal control group lasted on average 5 days and consisted of the following successive estrous phases: proestrus, estrus, metestrus and two phases of diestrus. In the LTZ group, the estrous cycle was blocked in the diestrus phase (Fig. 1b). The cyclic appearance of the different phases of the estrous cycle, starting with the proestrus phase, resumed in animals receiving both clomiphene citrate and metformin after 2 days of administration (Fig. 1c). Following treatment with the aqueous extract of $M$. arboreus leaves, proestrus appeared after 24 days of administration at the dose of $20 \mathrm{mg} / \mathrm{kg}$ (Fig. 1d) and after 18 days of administration at doses of 110 and $200 \mathrm{mg} / \mathrm{kg}$, respectively (Fig. 1e and f).

\section{Serum levels of testosterone, $\mathrm{LH}$ and estradiol}

Serum levels of testosterone increased by $481 \%(p<$ 0.001) in the LTZ group as compared with the normal control group (Fig. 2a). The combined administration of clomiphene citrate and metformin decreased this parameter by $92 \%(p<0.001)$ as compared with the LTZ group. The aqueous extract of $M$. arboreus leaves induced a similar effect at doses of $20 \mathrm{mg} / \mathrm{kg}$ (37\% induction; $p<$ 0.001 ) and $110 \mathrm{mg} / \mathrm{kg}$ (95\% induction; $p<0.001$ ).

Figure $2 \mathrm{~b}$ shows that serum levels of LH increased by $310 \%(p<0.001)$ in the LTZ group as compared with the normal control group. The combined administration of clomiphene citrate and metformin decreased this

Table 1 Effects of the leaf aqueous extract of M. arboreus on body and abdominal fat weights

\begin{tabular}{lllll}
\hline Groups & $\begin{array}{l}\text { Body weight before letrozole } \\
\text { administration } \mathbf{( g )}\end{array}$ & $\begin{array}{l}\text { Body weight following a 21-day } \\
\text { administration of letrozole } \mathbf{( g )}\end{array}$ & $\begin{array}{l}\text { Body weight following } \\
\text { a 30-day treatment (g) }\end{array}$ & $\begin{array}{l}\text { Abdominal fat weight } \\
(\mathbf{g} / 100 \mathbf{g} \text { of BW) }\end{array}$ \\
\hline NC & $161.60 \pm 2.38$ & $164.75 \pm 0.69$ & $176.60 \pm 3.63$ & $2.52 \pm 0.32$ \\
LTZ & $159.89 \pm 2.29$ & $186.50 \pm 1.98^{* * * *}$ & $195.50 \pm 9.93^{*}$ & $3.55 \pm 0.16$ \\
LTZ + CC + MET & $158.71 \pm 2.74$ & $186.50 \pm 1.98^{* * *}$ & $144.50 \pm 20.36^{* * *, \# \# \#}$ & $0.61 \pm 0.09^{* * *, \# \# \#}$ \\
LTZ + AE 20 & $162.38 \pm 2.78$ & $183.40 \pm 2.30^{* * *}$ & $190.33 \pm 12.07$ & $2.43 \pm 0.45$ \\
LTZ + AE 110 & $157.90 \pm 3.31$ & $186.50 \pm 1.98^{* * *}$ & $162.44 \pm 17.61^{\# \# \#}$ & $2.37 \pm 0.23^{\#}$ \\
LTZ + AE 200 & $157.90 \pm 3.31$ & $184.60 \pm 1.96^{* * *}$ & $187.12 \pm 12.03$ & $3.17 \pm 0.18$ \\
\hline
\end{tabular}

$N C$ normal control; $L T Z$ letrozole; CC clomiphene citrate; MET metformine; $A E$ leaf aqueous extract of $M$. arboreus; $B W$ body weight. Results are presented as mean \pm S.E.M., $n=5$. ${ }^{*} p<0.05$ and ${ }^{* * *} p<0.001$ vs NC; $\# p<0.05$ and \#\#\# $p<0.001$ vs LTZ 


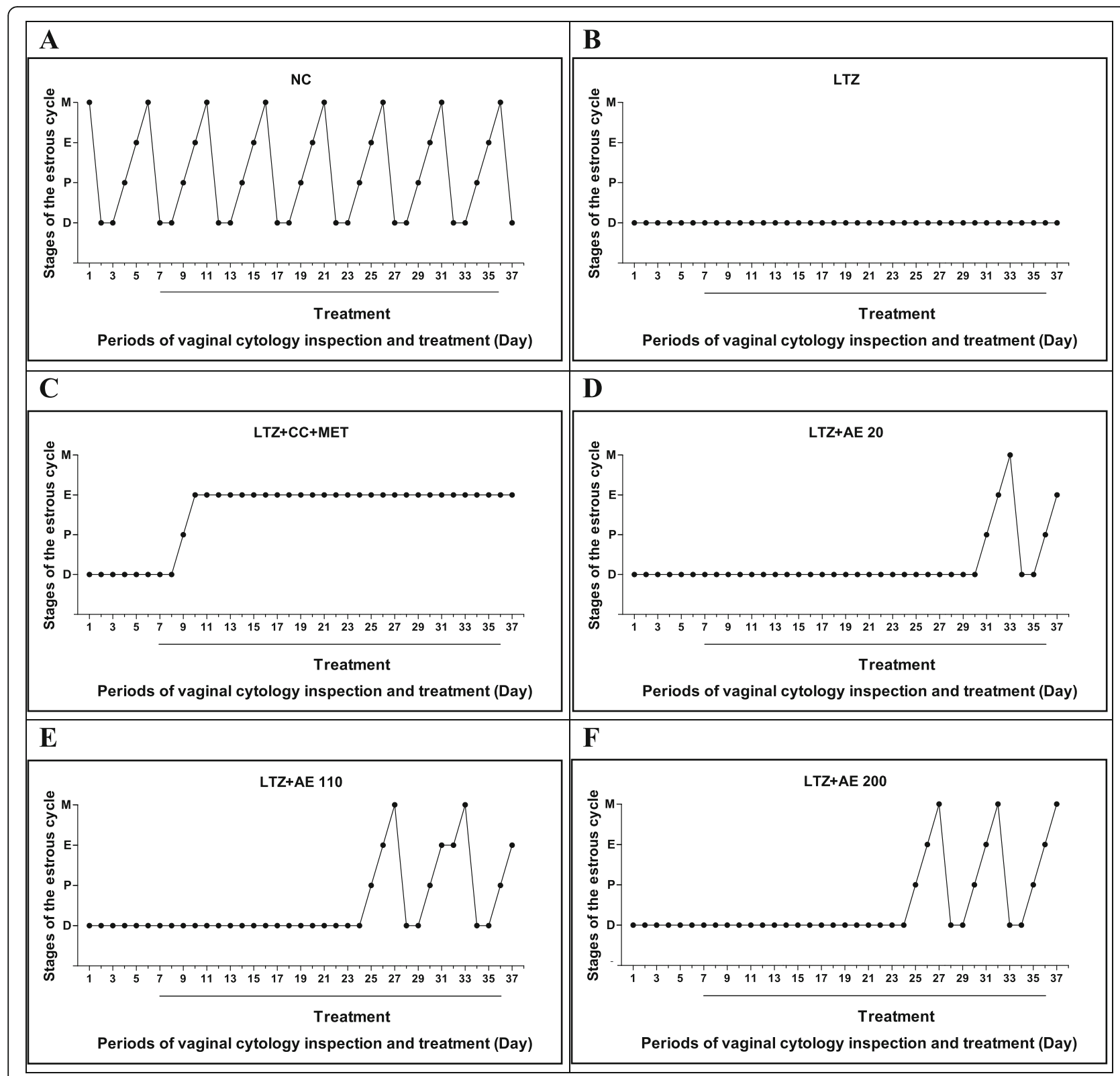

Fig. 1 Effects of the leaf aqueous extract of M. arboreus on the estrous cycle. NC: normal control; LTZ: letrozole; CC: clomiphene citrate; MET: metformine; AE: leaf aqueous extract of $M$. arboreus. Data show the most represented phase of the estrous cycle in each group, $n=5$. $P=$ proestrous stage-nucleated epithelial cells, $\mathrm{E}=$ estrous stage-cornified cells, $\mathrm{M}=$ metestrus-nucleated, cornified and leucocytes, and $\mathrm{D}=$ diestrous stage-leucocytes

parameter by $77 \%(p<0.001)$ in comparison with the LTZ group. The aqueous extract of $M$. arboreus leaves induced a similar effect at tested doses.

Figure $2 \mathrm{c}$ shows that serum levels of estradiol decreased by $84 \%(p<0.001)$ in the LTZ group as compared with the normal control group. The combined administration of clomiphene citrate and metformin increased this parameter by $764 \%(p<0.001)$ as compared with the LTZ group. The aqueous extract of $M$. arboreus leaves also induced a similar effect as it increased serum levels of estradiol by 74, 219 and $87 \%$ at doses of 20,110 and $200 \mathrm{mg} / \mathrm{kg}$, respectively.

\section{Histological score of the ovaries}

The histological score of the ovaries presented in Table 2 shows that the number of primary follicles decreased by $53 \%(p<0.05)$ in the LTZ group as compared with the normal control group. The combined administration of clomiphene citrate and metformin reversed this effect as it increased the number of primary follicles by $233 \%$ 


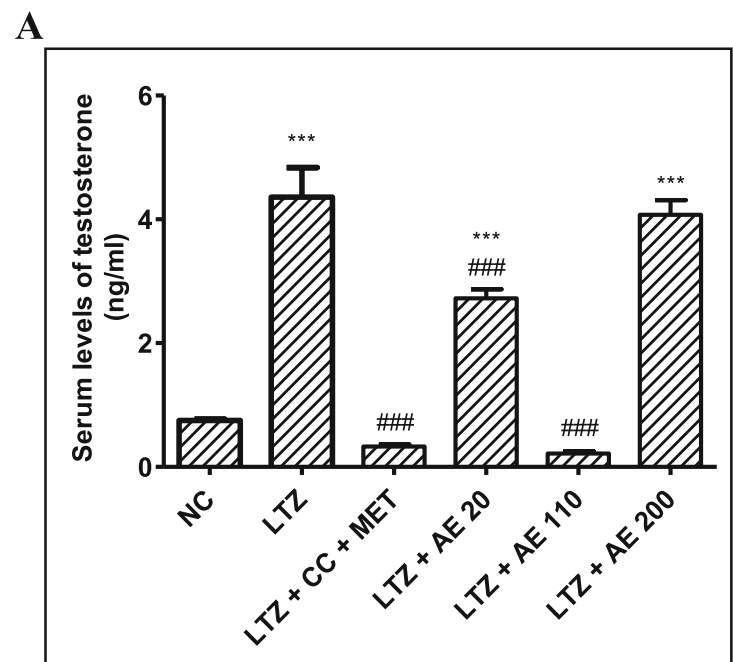

B

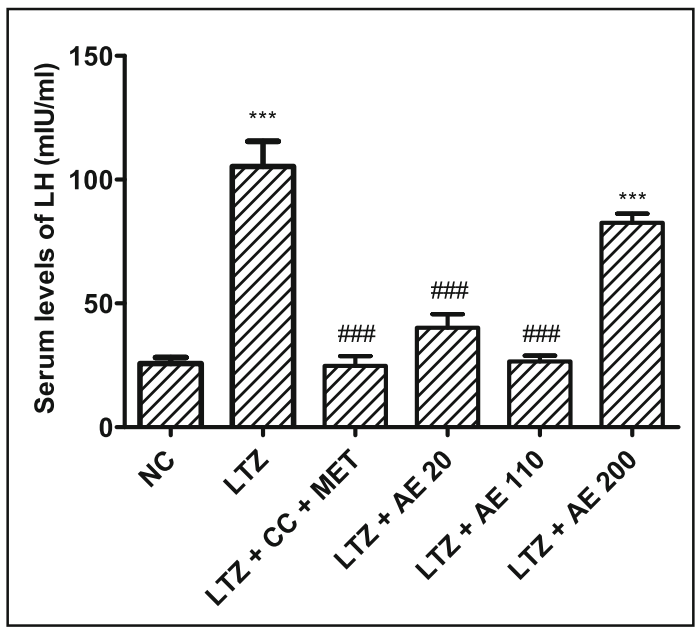

C

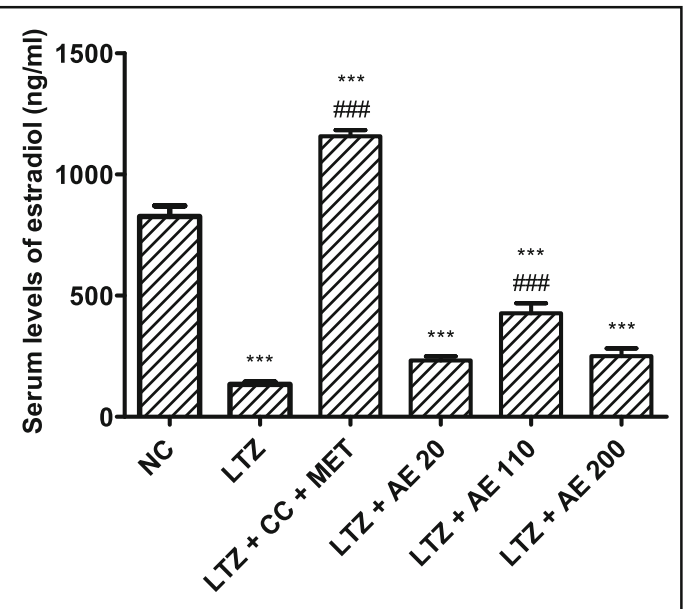

Fig. 2 Serum levels of testosterone (a), LH (b) and estradiol (c) following treatments. NC: normal control; LTZ: letrozole; CC: clomiphene citrate; MET: metformine; AE: leaf aqueous extract of $M$. arboreus. Results are presented as mean S.E.M., $n=5 .{ }^{* *} p<0.001$ vs NC; \#\#\# $p<0.001$ vs LTZ

$(p<0.001)$ in comparison with the LTZ group. A similar effect was observed with the aqueous extract of $M$. arboreus leaves which increased the number of primary follicles by 300,433 and $500 \%(p<0.001)$ at doses of 20 , 110 and $200 \mathrm{mg} / \mathrm{kg}$, respectively, as compared with the LTZ control.

The number of secondary follicles decreased by $71 \%$ in the LTZ group as compared with the normal control group. The combined administration of clomiphene citrate and metformin increased this parameter by $494 \%$ $(p<0.05)$ in comparison with the LTZ group. A similar effect was observed with the aqueous extract of $M$. arboreus leaves at tested doses.

The number of tertiary follicles decreased by $36 \%$ in the LTZ group as compared with the normal control group. Following the combined administration of clomiphene citrate and metformine, the number of tertiary follicles increased by $329 \%(p<0.001)$ in comparison with the LTZ group. A similar observation was made with the aqueous extract of $M$. arboreus leaves at tested doses.

The number of Graafian follicles decreased by $33 \%$ in the LTZ group as compared with the normal control group. Following the combined administration of clomiphene citrate and metformin, the number of Graafian follicles increased by $138 \%(p<0.01)$ in comparison with the LTZ group. A similar observation was made with the aqueous extract of $M$. arboreus leaves at tested doses.

The number of corpora lutea decreased by $60 \%(p<$ 0.001 ) in the LTZ group as compared with the normal control group. The combined administration of clomiphene citrate and metformin increased it by $110 \%(p<$ 0.001 ) in comparison with the LTZ group. A similar observation was made with the aqueous extract of $M$. arboreus leaves at tested doses.

The number of atretic follicles increased by $89 \%(p<$ $0.001)$ in the LTZ group as compared to the normal control group. The combined administration of clomiphene citrate and metformin decreased it by $34 \%(p<$ 0.001 ) in comparison with the LTZ group. The aqueous extract of $M$. arboreus leaves induced a similar effect at tested doses.

In the ovaries of normal control animals, no cystic follicles were identified. However, in the ovaries of animals in the LTZ group, the number of cystic follicles was on average $13.25 \pm 0.80(p<0.001)$. This number decreased by $82 \%(p<0.001)$ following the co-treatment with clomiphene citrate and metformin, in comparison with 
Table 2 Effects of the leaf aqueous extract of $M$. arboreus on ovarian follicle growth and maturation

\begin{tabular}{|c|c|c|c|c|c|c|c|}
\hline Groups & Primary follicles & Secondary follicles & Tertiary follicles & Graafian follicles & Corpora lutea & Cystic follicles & Atretic follicles \\
\hline NC & $3.20 \pm 0.49$ & $2.80 \pm 0.20$ & $2.20 \pm 0.37$ & $2.40 \pm 0.24$ & $12.00 \pm 1.26$ & $0.00 \pm 0.00$ & $5.60 \pm 0.51$ \\
\hline LTZ & $1.50 \pm 0.22^{*}$ & $0.80 \pm 0.37$ & $1.40 \pm 0.24$ & $1.60 \pm 0.24$ & $4.75 \pm 0.19^{* * *}$ & $13.25 \pm 0.79^{* * *}$ & $10.60 \pm 0.60^{* * *}$ \\
\hline $\mathrm{LTZ}+\mathrm{CC}+\mathrm{MET}$ & $5.00 \pm 0.32^{*}$ & $4.75 \pm 0.37^{\#}$ & 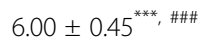 & $3.80 \pm 0.58^{\# \#}$ & $10.00 \pm 1.14^{\# \# \#}$ & $2.33 \pm 0.18^{* *}, \# \#$ & $7.00 \pm 0.45^{\# \# \#}$ \\
\hline $\mathrm{LTZ}+\mathrm{AE} 20$ & $6.00 \pm 0.32^{* * *}, \# \#$ & $5.00 \pm 0.32^{\#}$ & $3.33 \pm 0.18^{\#}$ & 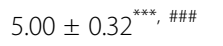 & $9.50 \pm 0.50^{\# \#}$ & $3.67 \pm 0.36^{* * *}, \# \# \#$ & $7.20 \pm 0.37^{\# \#}$ \\
\hline$L T Z+A E 110$ & $8.00 \pm 0.32^{* * * *}, \# \#$ & $8.80 \pm 1.07^{* * * *}$, \#\#\# & $4.00 \pm 0.32^{*}, \# \# \#$ & $5.25 \pm 0.19^{* * * *}$,\#\# & $6.20 \pm 0.58^{* * *}$ & $4.00 \pm 0.32^{* * * *}$,\#\#\# & $6.60 \pm 0.81^{\# \# \#}$ \\
\hline $\mathrm{LTZ}+\mathrm{AE} 200$ & $9.00 \pm 0.55^{* * *}, \# \#$ & $9.20 \pm 1.59^{* * *}, \# \#$ & $3.40 \pm 0.51^{\# \#}$ & 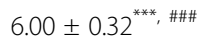 & $7.33 \pm 0.36^{* *}$ & 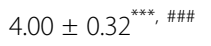 & $7.60 \pm 0.25^{\# \#}$ \\
\hline
\end{tabular}

NC normal control; LTZ letrozole; CC clomiphene citrate; MET metformine; $A E$ leaf aqueous extract of $M$. arboreus. Results are presented as mean S.E.M., $n=5$. ${ }^{*} p<$ $0.05,{ }^{* *} p<0.01$ and ${ }^{* * *} p<0.001$ vs NC. ${ }^{\#} p<0.05,{ }^{\# \#} p<0.01$ and ${ }^{\# \# \#} p<0.001$ vs LTZ

the LTZ group. The aqueous extract of $M$. arboreus leaves induced a similar effect at tested doses.

Figure 3 shows photomicrographs of the ovaries of experimental animals where the following follicles are identified: tertiary follicles, Graafian follicles, corpus luteum, cystic and atretic follicles. Ovarian sections of the normal control group exhibited normal ovarian morphology with mature follicles (tertiary and Graafian follicles) and corpora lutea which is an indicator of ovulation. In PCOS animals (in the LTZ group), the microarchitecture of the ovaries was dominated by the presence of cystic and atretic follicles. Following treatments, ovarian sections exhibited mature follicles, corpora lutea and few cystic and atretic follicles.

\section{Ovarian levels of malondialdehyde, catalase and total peroxidases}

Ovarian levels of malondialdehyde (MDA) increased by $16 \%$ in the LTZ group as compared with the normal control group (Table 3). The combined administration of clomiphene citrate and metformin decreased this parameter by $33 \%(p<0.01)$ in comparison with the LTZ group. The aqueous extract of $M$. arboreus leaves induced a similar effect at doses of $20 \mathrm{mg} / \mathrm{kg}$ ( $27 \%$ induction, $p<0.05$ ) and $110 \mathrm{mg} / \mathrm{kg}$ (46\% induction, $p<0.001$ ), respectively.

The ovarian level of catalase decreased by $25 \%$ ( $p<$ $0.001)$ in the LTZ group as compared with the normal control group (Table 3). The combined administration of clomiphene citrate and metformin did not alter ovarian level of catalase which remained similar to that of the LTZ group. The aqueous extract of $M$. arboreus leaves, in contrast, increased this parameter by $25 \%(p<$ 0.05 ) at the dose of $20 \mathrm{mg} / \mathrm{kg}$ and $14 \%$ at doses of 110 and $200 \mathrm{mg} / \mathrm{kg}$, in comparison with the LTZ group.

Table 3 also shows that the ovarian level of total peroxidases decreased by $40 \%(p<0.01)$ in the LTZ group as compared with the normal control group. The combined administration of clomiphene citrate and metformin increased this parameter by $13 \%$ in comparison
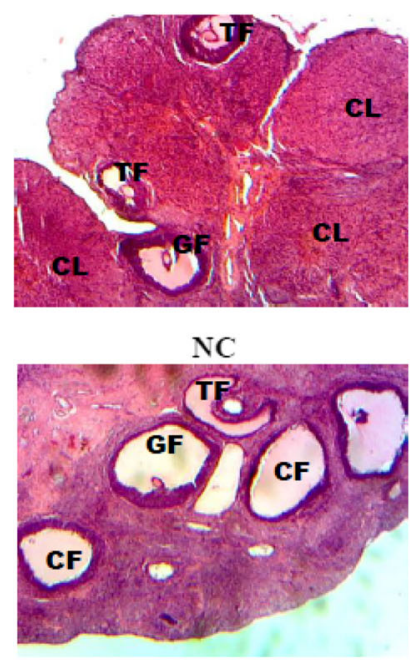

LTZ+AE 20

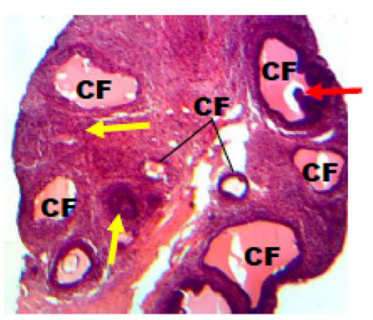

LTZ

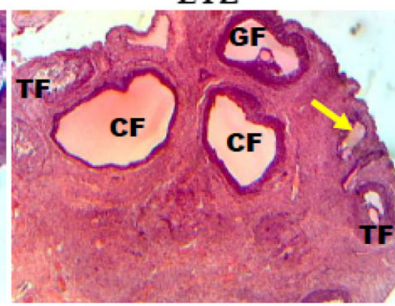

LTZ + AE 110

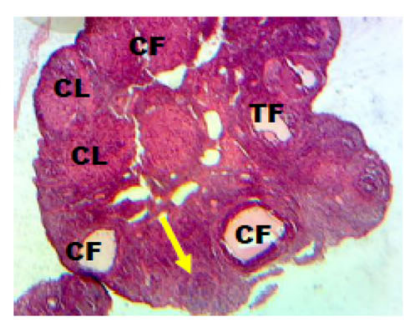

$\mathrm{LTZ}+\mathrm{CC}+\mathrm{MET}$

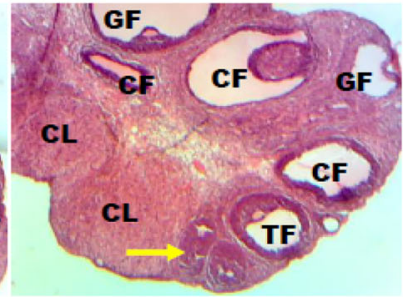

LTZ+AE 200

Fig. 3 Photomicrographs (X 200, hematoxylin and eosin staining) of the ovaries of experimental animals. NC: normal control; LTZ: letrozole; CC: clomiphene citrate; MET: metformine; AE: leaf aqueous extract of M. arboreus. TF: tertiary follicles; GF: Graafian follicles; CL: corpus luteum; CF: cystic follicles; red arrow: degenerating oocyte; yellow arrow: atretic follicles 
Table 3 Ovarian levels of malondialdehyde, catalase and total peroxydases, following treatments

\begin{tabular}{llll}
\hline Groups & Malondialdehyde $(\mu \mathrm{M})$ & $\begin{array}{l}\text { Catalase } \\
(\boldsymbol{\mu m o l e / g} \text { of total proteins) }\end{array}$ & $\begin{array}{l}\text { Total peroxidases } \\
(\mathbf{m M} / \mathbf{g} \text { of total proteins) }\end{array}$ \\
\hline NC & $1.60 \pm 0.14$ & $2.09 \pm 0.11$ & $11.13 \pm 1.32$ \\
LTZ & $1.86 \pm 0.11$ & $1.57 \pm 0.03^{* * *}$ & $6.64 \pm 0.37^{* *}$ \\
LTZ + CC + MET & $1.25 \pm 0.09^{\# \#}$ & $1.47 \pm 0.11^{* * *}$ & $7.53 \pm 0.38^{*}$ \\
LTZ+ AE 20 & $1.36 \pm 0.032^{\#}$ & $1.96 \pm 0.07^{\#}$ & $7.84 \pm 0.06$ \\
LTZ + AE 110 & $1.01 \pm 0.10^{* * \# \# \#}$ & $1.79 \pm 0.05$ & $8.27 \pm 0.71$ \\
LTZ + AE 200 & $1.73 \pm 0.08$ & $1.79 \pm 0.05$ & $10.17 \pm 1.12^{\#}$
\end{tabular}

NC normal control; LTZ letrozole; CC clomiphene citrate; MET metformine; $A E$ leaf aqueous extract of $M$. arboreus. Results are presented as mean S.E.M., $n=5 .{ }^{*} p<$ $0.05,{ }^{* *} p<0.01$ and ${ }^{* * *} p<0.001$ vs NC. ${ }^{\#} p<0.05$, ${ }^{\# \#} p<0.01$ and ${ }^{\# \# \#} p<0.001$ vs LTZ

with the LTZ group. A similar effect was observed with the aqueous extract of $M$. arboreus leaves which increased ovarian level of total peroxidases by 18,25 and $53 \%$ at doses of 20,110 and $200 \mathrm{mg} / \mathrm{kg}$, respectively, in comparison with the LTZ group.

\section{Relative uterine weight and uterine epithelial height}

Letrozole (LTZ) decreased the relative uterine weight by $67 \%(p<0.001)$ as compared with the normal control group (Fig. 4a). The combined administration of clomiphene citrate and metformin increased this parameter by $48 \%$ as compared with the LTZ group. In contrast, following treatment with the aqueous extract of $M$. arboreus leaves, the relative uterine weight further decreased: $18 \%$ induction at $20 \mathrm{mg} / \mathrm{kg}, 41 \%$ induction at $110 \mathrm{mg} / \mathrm{kg}$ and $21 \%$ induction at $200 \mathrm{mg} / \mathrm{kg}$.

The uterine epithelial height of animals in the LTZ group decreased by $39 \%(p<0.05)$ as compared with the normal control group (Fig. 4b). Co-treatment with clomiphene citrate and metformin increased this parameter by $225 \%(p<0.001)$ as compared with the LTZ group. The aqueous extract of $M$. arboreus leaves induced a similar effect as it increased uterine epithelial height by $82(p<0.01), 63(p<0.05)$ and $90 \%$ $(p<0.001)$ at 20,110 and $200 \mathrm{mg} / \mathrm{kg}$, respectively, in comparison with the LTZ group.

Figure 5 shows that the uterus of animals in the normal control group was lined by a tall cuboidal epithelium. In animals of the LTZ group, the uterus was lined by a low cuboidal epithelium. Co-treatment with clomiphene citrate and metformin changed uterine epithelial cell morphology that became cylindrical. Treatment with the aqueous extract of $M$. arboreus leaves also induced the hypertrophy of uterine epithelial cells at tested doses.

\section{Fertility index and gestation rate}

Fertility index went from $66.67 \%$ in the normal control group to $0 \%$ in the LTZ group (Table 4). Co-treatment with clomiphene citrate and metformin, as well as the

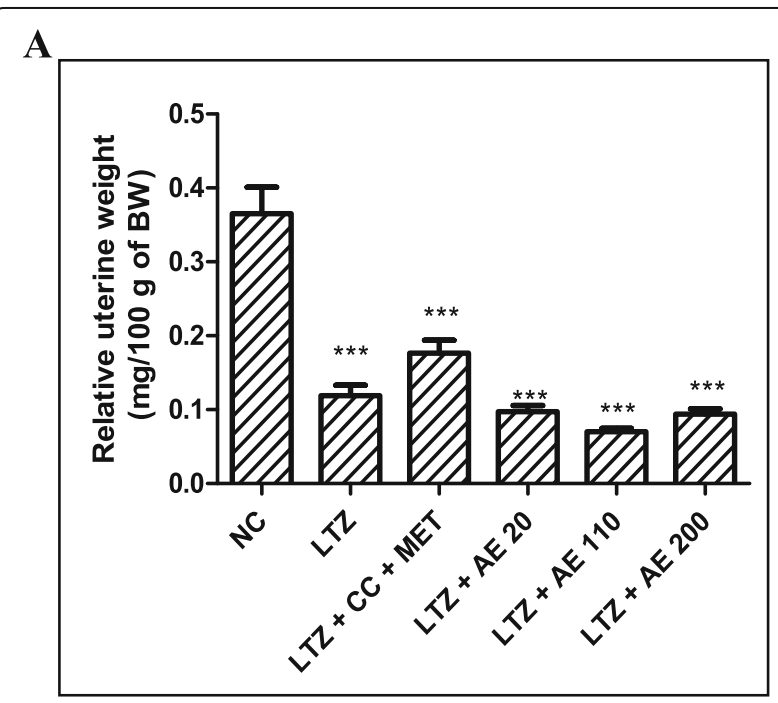

B

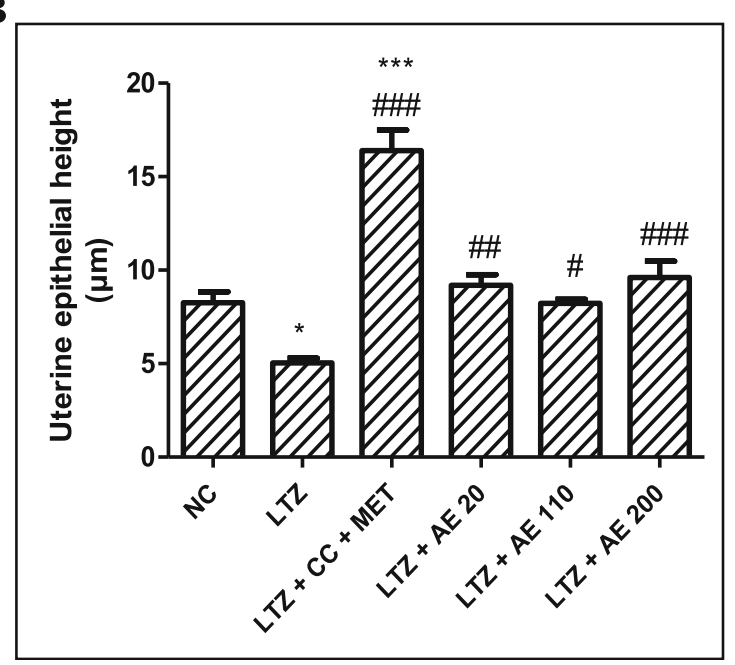

Fig. 4 Relative uterine weight (a) and uterine epithelial height (b) following treatments. NC: normal control; LTZ: letrozole; CC: clomiphene citrate; MET: metformine; AE: leaf aqueous extract of $M$. arboreus. Results are presented as mean S.E.M., $n=5$. ${ }^{*} p<0.05$ and ${ }^{* * *} p<0.001$ vs NC; ${ }^{\#} p<0.05,{ }^{\# \#} p<0.01$ and ${ }^{\# \# \#} p<0.001$ vs LTZ 


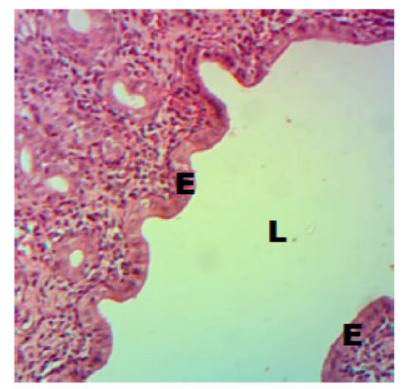

NC

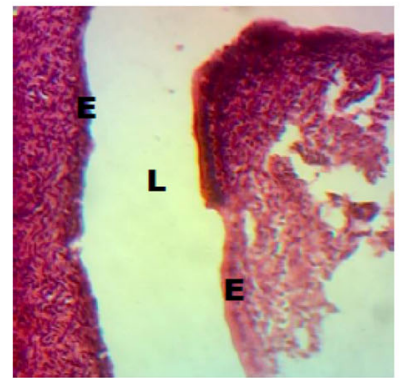

LTZ+AE 20

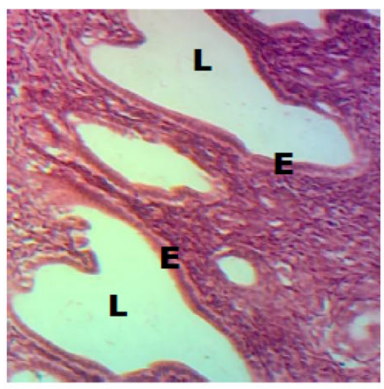

LTZ

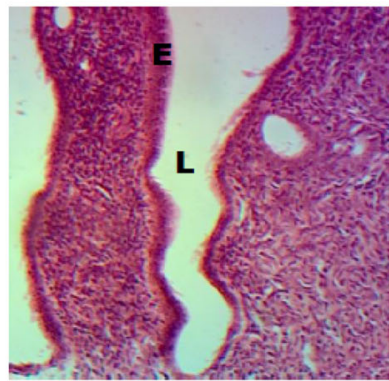

LTZ+AE 110

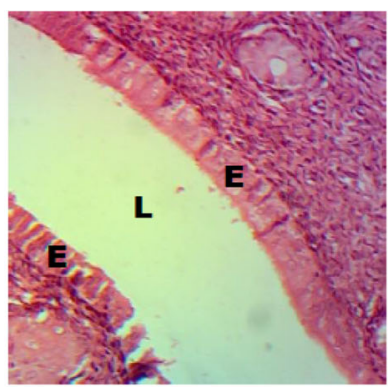

$\mathbf{L T Z}+\mathbf{C C}+\mathbf{M E T}$

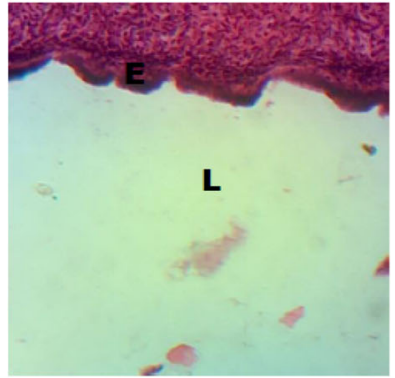

LTZ+AE 200

Fig. 5 Photomicrographs (X 100, hematoxylin and eosin staining) of the uterus of experimental animals. NC: normal control; LTZ: letrozole; CC: clomiphene citrate; MET: metformine; AE: leaf aqueous extract of M. arboreus. BW: body weight; E: epithelium; L: lumen

aqueous extract of $M$. arboreus leaves, increased this parameter by at least $66.67 \%$.

Gestation rate went from $100 \%$ in the normal control group to $0 \%$ in the LTZ group (Table 4). Co-treatment with clomiphene citrate and metformin, as well as the aqueous extract of $M$. arboreus leaves, increased gestation rate which went from $0 \%$ in the LTZ group to $100 \%$ following treatment.

\section{Discussion}

The present study aimed to investigate the ability of the aqueous extract of $M$. arboreus leaves to relieve PCOSrelated conditions including infertility, in rats. PCOS was induced with letrozole following the method described by Ndeingang et al. [2]. Since letrozole is a reversible aromatase inhibitor $[4,22]$, its administration was not

Table 4 Effects of the leaf aqueous extract of M. arboreus on fertility index and gestation rate

\begin{tabular}{lll}
\hline Groups & Fertility index (\%) & Gestation rate (\%) \\
\hline NC & 66.67 & 100 \\
LTZ & 0 & 0 \\
LTZ+ CC+ MET & 75 & 100 \\
LTZ + AE 20 & 66.67 & 100 \\
LTZ + AE 110 & 66.67 & 100 \\
LTZ + AE 200 & 75 & 100 \\
\hline
\end{tabular}

NC normal control; LTZ letrozole; CC clomiphene citrate; MET metformine; $A E$ leaf aqueous extract of $M$. arboreus interrupted during treatments which lasted 30 days. In agreement with previous reports [2, 20, 22, 23], results showed that letrozole induced overweight, blocked the estrous cycle in the diestrus phase, increased serum levels of testosterone and $\mathrm{LH}$, promoted ovarian cyst formation and induced infertility. By inhibiting aromatase activity, letrozole induces an accumulation of androgens in the blood stream leading to hyperandrogenism [41] with the resulting blockage of the estrous cycle in the diestrus phase, since vaginal smears undergo cytological changes only according to the cyclical variations of serum estradiol levels [34]. Excess androgen stimulates an excessive pituitary secretion of $\mathrm{LH}$ by promoting an overproduction of GnRH by the hypothalamic neurons [4]. Indeed, hyperandrogenism was found to induce an excessive release of insulin by pancreatic $\beta$-cells [5]. High quantities of insulin were reported to increase glutamate levels in the brain tissue of animals with letrozole-induced PCOS, and elevated amounts of this excitatory neurotransmitter are known to induce an overstimulation of GnRH and $\mathrm{LH}$ release [4]. Hyperinsulinemia was also suggested to induce weight gain as insulin was found to inhibit the activity of adenosine monophosphate-activated protein kinase (AMPK) [42], resulting in the enhancement of acetyl CoA carboxylase (ACC) activity, which promotes the biosynthesis of fatty acids $[43,44]$. The resulting fat accumulation might account for the observed weight gain following letrozole administration. In addition, insulin increases the bioavailability of insulin-like growth factor 1 (IGF-1) and both 
insulin and IGF-1 were reported to amplify the effects of LH on granulosa cells, leading to their premature differentiation which results in follicular growth arrest, anovulation and cyst formation [7, 8]. All these events would have contributed to reduce fertility index and gestation rate in PCOS rats.

Following treatments, the aqueous extract of $M$. arboreus leaves decreased animal body weight and reduced fat accumulation. These results suggest that $M$. arboreus would have increased the activity of AMPK in peripheral tissues and therefore, reduced the activity of ACC. Low activity of ACC was associated with reduced lipogenesis and weight loss $[43,44]$. M. arboreus also induced the resumption of the estrous cycle after it was arrested in the diestrus phase following letrozole administration. This result was associated with decreased levels of LH and testosterone, increased levels of estradiol, and a restored ovarian dynamic (improved ovarian follicle growth and maturation, reduction of follicle atresia, and development and maintenance of the corpora lutea). These results indicate that $M$. arboreus has reduced the inhibitory effect of letrozole on aromatase activity leading to decreased levels of testosterone and LH, and increased levels of estradiol. This estradiol would have stimulated uterine epithelial cells growth. Such an uterotrophic effect is known to be an estrogen receptor alpha mediated event $[45,46]$. Moreover, the improvement of ovarian dynamic suggests that $M$. arboreus would have lowered androgen stimulation of insulin secretion by pancreatic $\beta$-cells as it reduced circulating free androgen. Since hyperinsulinemia induced by hyperandrogenism was associated with premature maturation and luteinization of granulosa cells, follicular growth arrest, anovulation and cyst formation $[7,8]$, results suggest that, by reducing testosterone level and probably insulin production by pancreatic $\beta$-cells, $M$. arboreus would have consequently reduced the hyperinsulinemic signal impairing ovarian dynamic, and would have restored it.

The restoration of ovarian dynamic was characterized by the appearance of increased number of Graafian follicles (indicating follicular development and maturation), corpora lutea (the hallmark of ovulation), and reduced number of atretic follicles. Follicular atresia observed in PCOS rats was attributed to increased apoptosis of granulosa cells as a result of low estradiol levels [47]. Oxidative stress was reported to initiate cell apoptosis [48], and substances with antioxidant properties were found reducing oxidative stress $[47,49,50]$ and follicular atresia $[47,50]$ in PCOS rats. Additionally, estradiol was reported to be a survival factor for the maintenance of granulosa cells [47]. Therefore, low levels of estradiol in PCOS animals would have promoted oxidative stressmediated granulosa cell apoptosis and the resulting follicular atresia. By increasing the production of estradiol,
M. arboreus would have reduced oxidative stress in the ovaries of treated animals as evidenced by low levels of malondialdehyde (MDA, a lipid peroxidation byproduct and a marker of oxidative stress) and increased levels of antioxidant enzymes (catalase and total peroxidases), thus stimulating the resumption of follicular development and maturation, as shown by the increased number of Graafian follicles. This ability of $M$. arboreus to reduce oxidative stress in the ovaries of PCOS animals may be also attributed to its reported antioxidative properties $[29,51,52]$.

The effects induced by the aqueous extract of $M$. arboreus leaves on serum levels of hormones and ovarian dynamic would have contributed to the resumption of the estrous cycle, the hypertrophy of uterine epithelial cells and finally the restoration of PCOS rat fertility. Indeed, results showed that fertility index and gestation rate increased in animals treated with the aqueous extract of $M$. arboreus leaves in comparison with those receiving letrozole only, in which both parameters were null. Following treatment with the aqueous extract of $M$. arboreus leaves, more than $66 \%$ of female rats were pregnant and $100 \%$ of gestational female rats had viable and healthy fetuses at birth. These results corrorate the observations previously made by Awounfack et al. [30] in healthy animals and further support ethnobotanical data reporting the efficacy of $M$. arboreus in the treatment of female infertility [24, 28-30].

\section{Conclusions}

The present study showed that the aqueous extract of $M$. arboreus leaves improved PCOS-associated conditions as it reduced weight gain, restored estrous cycle, decreased abdominal fat accumulation, and serum levels of testosterone and LH. M. arboreus also increased serum levels of estradiol which would have contributed to induce uterine epithelial cell hypertrophy, and to reduce ovarian oxidative stress and follicular atresia. All these events would have contributed to restore ovarian dynamic and to increase fertility index and gestation rate in treated animals. These results support at least in part, the traditional use of $M$. arboreus against female infertility and suggest that this plant could be a promising alternative treatment to improve symptoms associated with different PCOS phenotypes.

\footnotetext{
Abbreviations

PCOS: Polycystic ovarian syndrome; GnRH: Gonadotropin releasing hormone; LH: Luteinizing hormone; IGF-1: Insulin-like growth factor 1; IVF: In vitro fertilization; LOD : Laparoscopic ovarian drilling; SEM : Standard error of the mean; NC: Normal control; LTZ: Letrozole; CC: Clomiphene citrate; MET: Metformin; EA: Leaf aqueous extract of M. arboreus; E: Uterine epithelium; L: Uterine lumen; MDA: Malondialdehyde; SOD: Superoxide dismutase
} 


\section{Acknowledgments}

The authors are thankful to the Research Unit of Animal Physiology and Phytopharmacology of the University of Dschang for material support. Special thanks to Mr. Takala Jean Pierre who performed histological procedure, Mr. Lieunang W. Boris who carried out the determination of hormones in serum samples, Dr. Vemo Bertin Narcisse who carried out the determination of oxidative stress-related parameters in ovary homogenates, and Dr. Mvo Denis Chuo (an English speaking colleague) who helped revise the manuscript.

\section{Authors' contributions}

MAM, FIMT and DJ were involved in the design, interpretation and analysis of data. MAM supervised the study and drafted the present article. FIMT performed experimental works; CFA provided M. arboreus sample, prepared the aqueous extract of M. arboreus and helped for experimental works. All authors read and approved the final manuscript.

\section{Funding}

This research received no specific funding and was performed at the Research Unit of Animal Physiology and Phytopharmacology of the University of Dschang, as part of the employment of the authors.

\section{Availability of data and materials}

All the data used to support the findings of this study are available from the corresponding author upon reasonable request.

\section{Ethics approval and consent to participate}

Animal housing and all experiments were conducted in conformity with the European Union on Animal Care (CEECouncil 86/609) guidelines adopted by the Institutional Ethics Committee of the Cameroon Ministry of Scientific Research and Technology Innovation (Reg. no. FWA-IRD 0001954, 04/09/2006).

\section{Consent for publication}

Not applicable.

\section{Competing interests}

The authors declare that they have no competing interests.

\section{Author details}

'Research Unit of Animal Physiology and Phytopharmacology, University of Dschang, P.O. Box 67, Dschang, Cameroon. ${ }^{2}$ Laboratory of Animal Physiology, University of Yaounde 1, P.O. Box 812, Yaounde, Cameroon.

\section{Received: 26 September 2019 Accepted: 1 September 2020}

\section{Published online: 11 September 2020}

\section{References}

1. Joshi B, Mukherjee S, Patil A, Purandare A, Chauhan S, Vaidya R. A crosssectional study of polycystic ovarian syndrome among adolescent and young girls in Mumbai, India. Indian J Endocrinol Metab. 2014;18:317.

2. Ndeingang EC, Defo Deeh PB, Watcho P, Kamanyi A. Phyllanthus muellerianus (Euphorbiaceae) restores ovarian functions in letrozole-induced polycystic ovarian syndrome in rats. Evid Based Complement Alternat Med. 2019;2019:1-16.

3. Yagmur E, Bast E, Mühlfeld AS, Koch A, Weiskirchen R, Tacke F, Neulen J. High prevalence of sticky platelet syndrome in patients with infertility and pregnancy loss. J Clin Med. 2019;8:1328.

4. Chaudhari N, Dawalbhakta M, Nampoothiri L. GnRH dysregulation in polycystic ovarian syndrome (PCOS) is a manifestation of an altered neurotransmitter profile. Reprod Biol Endocrinol. 2018;16:37.

5. Xu W, Morford J, Mauvais-Jarvis F. Emerging role of testosterone in pancreatic $\beta$-cell function and insulin secretion. J Endocrinol. 2019. https:// doi.org/10.1530/JOE-18-0573.

6. Andersen PH, Kristensen K, Pedersen SB, Hjollund E, Schmitz O, Richelsen B. Effects of long-term total fasting and insulin on $\mathrm{Ob}$ gene expression in obese patients. Eur J Endocrinol. 1997;137:229-33.

7. Dou L, Zheng Y, Li L, Gui X, Chen Y, Yu M, Guo Y. The effect of cinnamon on polycystic ovary syndrome in a mouse model. Reprod Biol Endocrinol. 2018;16:99.

8. Allahbadia GN, Merchant R. Polycystic ovary syndrome and impact on health. Middle East Fertil Soc J. 2011;16:19-37.
9. Costello MF, Shrestha B, Eden J, Johnson NP, Sjoblom P. Metformin versus oral contraceptive pill in polycystic ovary syndrome: a Cochrane review. Hum Reprod. 2007;22(5):1200-9.

10. Yang YM, Choi EJ. Efficacy and safety of metformin or oral contraceptives, or both in polycystic ovary syndrome. Ther Clin Risk Manag. 2015;11:1345-53.

11. Lord JM, Flight IHK, Norman RJ. Metformin in polycystic ovary syndrome: systematic review and meta-analysis. BMJ. 2003;327:951-3.

12. Legro RS, Barnhart HX, Schlaff WD, Carr BR, Diamond MP, Carson SA. Clomiphene, metformin or both for infertility in the polycystic ovary syndrome. N Engl J Med. 2007;356:551-66.

13. Kafy S, Tulandi T. New advances in ovulation induction. Curr Opin Obstet Gynecol. 2007;19:248-52.

14. Tannys D, Ottawa A. Vancouver. Déclenchement de l'ovulation en présence du SOPK. Directive clinique de la SOGC. 2010;242:503-11.

15. Creanga AA, Bradley HM, McCormick C, Takacs WC. Use of metformin in polycystic ovary syndrome a metaanalysis. Obstet Gynecol. 2008;111:959-68.

16. Farquhar C, Brown J, Marjoribanks J. Laparoscopic drilling by diathermy or laser for ovulation induction in anovulatory polycystic ovary syndrome. Cochrane Database Syst Rev. 2012;6:CD001122.

17. Palomba S, Russo T, Orio F. Utérine effets of clomiphène citrate in women with polycystic ovary syndrome: a prospective controlled study. Hum Reprod. 2006;21:2823-9.

18. Mercorio F, Mercorio A, Di Spiezio SA, Barba GV, Pellicano M, Mappi C Evaluation of ovarian adhesion formation after laparoscopic ovarian drilling by second-look minilaparoscopy. Fertil Steril. 2008:89:1229-33.

19. Kabiri N, Mohammad R, Seyed R. Beneficieal effects of pioglitazone and metformin in murinr model of polycystic ovaries via improvement of chemerin gene up-regulation. J Pharm Sci. 2014;22:39.

20. Maharjan R, Nagar PS, Nampoothiri L. Effect of Aloe barbadensis mill. Formulation on Letrozole induced polycystic ovarian syndrome rat model. J Ayurveda Integr Med. 2010;1(4):273-9.

21. Jitendra PA, Pravin TA. Prospective use of Tephrosia purpurea in remedial treatment of PCOS, study in Wistar rat. ISCA J Biolo Sci. 2012;1:1-6.

22. Saiyed A, Jahan N, Makbul SAA, Ansari M, Bano H, Hajera HS. Effect of combination of Withania somnifera Dunal and Tribulus terrestris Linn on letrozole induced polycystic ovarian syndrome in rats. Integr Med Res. 2016; 5:293-300.

23. Lee YH, Yang H, Lee SR, Kwon SW, Hong EJ, Lee HW. Welsh Onion Root (Allium fistulosum) Restores Ovarian Functions from Letrozole InducedPolycystic Ovary Syndrome. Nutrients. 2018;10:10.

24. Burkill HM. In: Families JL, editor. The Useful Plants of West Tropical Africa, vol. 3. Kew: Royal Botanic Garden; 1985

25. Okafor JC. Myrianthus arboreus. P. Beauv. In: GJH G, Denton OA, editors. PROTA 2; Vegetables legumes. Wageningen: PROTA. Fountain; 2004. p. 31-8.

26. Agyare C, Ansah AO, Ossei PPS, Apenteng JA, Boakye YD. Wound healing and anti-infective properties of Myrianthus arboreus and Alchornea cordifolia. Med Chem. 2014;4:533-9.

27. Olonode ET, Aderibigbe AO, Bakre AG. Antinociceptive activity of the crude extract of Myrianthus arboreus P. Beauv (Cecropiaceae) in mice. J. Ethnopharmacol. 2015;171:94-8.

28. Adjanohoun JE, Aboubakar N, Dramane K, Ebot ME, Ekpere JA, Enow-Orock EG, Focho D, Gbile ZO, Kamanyi A, Kamsu Kom J, Keita A, Mbenkum I, Mbi CN, Mbiele AL, Mbome IL, Mubiru NK, Nancy L, Nkongmeneck B, Satabie B, Sofowora A, Tamze N, Wirmum CK. Traditional Medicine and Pharmacopoeia: Contribution to Ethnobotanical and Floristic Studies in Cameroon. Porto-Novo: OAU/STRC Publish House; 1996. p. 12-607.

29. Kasangana PB, Nachar A, Eid HM, Stevanovic T, Haddad PS. Root bark extracts of Myrianthus arboreus P. Beauv.(Cecropiaceae) exhibit antidiabetic potential by modulating hepatocyte glucose homeostasis. J Ethnopharmacol. 2018;211:117-25.

30. Awounfack C, Mvondo MA, Zingue S, Ateba SB, Djiogue S, Magnekou R, Tantoh Ndinteh D, Njamen D. Myrianthus arboreus P. Beauv (Cecropiaceae) extracts accelerates sexual maturation, and increases fertility index and gestational rate in female Wistar rats. Medicines. 2018;5:73.

31. Awounfack CF, Ateba SB, Zingue S, Riepouo Mouchili O, Njamen D. Safety evaluation (acuteandsub-acutestudies) of the aqueous extract of the leaves of Myrianthus arboreus P. Beauv. (Cecropiaceae) in Wistar rats. J Ethnopharmacol. 2016;194:169-78.

32. Belani M, Purohit N, Pillai P, Gupta S, Gupta S. Modulation of Steroidogenic pathway in rat Granulosa cells with subclinical cd exposure and insulin resistance: an impact on female fertility. BioMed Res Intern. 2014;2014:13. 
33. Mendoza-Rodriguez CA, Merchant-Larios H, Segura-Valdez ML. C-fos and estrogen receptor gene expression pattern in the rat uterine epithelium during the estrous cycle. Mol Reprod Develop. 2003;64:379-88.

34. Westwood FR. The female rat reproductive cycle: a practical histological guide to staging. Toxicol Path. 2008;36:375-84.

35. Mvondo MA, Minko Essono S, Bomba Tatsinkou FD, Ateba SB, Njamen D. The root aqueous extract of Entada africana Guill. Et Perr. (Mimosaceae) inhibits implant growth, alleviates dysmenorrhea, and restores ovarian dynamic in a rat model of endometriosis. Evid Based Complement Alternat Med. 2017;2017:1-15.

36. Mvondo MA, Messongue Mbollo NS, Njamen D. The ethanol extract of avocado [Persea americana Mill. (Lauraceae)] seeds reduced the hyperplastic effect of tamoxifen on uterine endometrium without changing its effect on the mammary gland. Adv Tradit Med. 2020. https://doi.org/10.1007/s13596020-00443-9.

37. Wilbur K, Bernhein F, Shapiro O. Determination of lipid peroxydation. Arch Biochem Biophys. 1949;24:3959-64.

38. Sinha KA. Colorimetric assay of catalase. Anal Biochem. 1972;47:389-94.

39. Habbu P, Shastry R, Mahadevan K, Hanumanthachar J, Das S. Hepatoprotective and antioxidant effects of argyreia speciosa in rats. Afr J Tradit Complement Altern Med. 2008:5(2):158-64.

40. Servais $\mathrm{S}$. Altération mitochondriale et stress oxydant pulmonaire en réponse à l'ozone : effet de l'âge et d'une suplémentation en oméga-3. Thèse de doctorat de l'université Claude Bernard, Lyon. 2004;1:17-40.

41. Kafali H, Iriadam M, Ozardali I, Demir N. Letrozole-induced polycystic ovaries in the rat: a new model for cystic ovariandisease. Arch Med Res. 2004;35: 103-8.

42. Valentine RJ, Coughlan KA, Ruderman NB, Saha AK. Insulin inhibits AMPK activity and phosphorylates AMPK Ser(4)(8)(5)/(4)(9)(1) through Akt in hepatocytes, myotubes and incubated rat skeletal muscle. Arch Biochem Biophys. 2014;562:62-9.

43. Zang M, Zuccollo A, Hou X, Nagata D, Walsh $K$, Herscovitz H, Brecher P, Ruderman NB, Cohen RA. AMP activated protein kinase is required for the lipid-lowering effect of metformin in insulin-resistant human HepG2 cells. Biol Chem. 2004;279(46):47898-905.

44. Sun L, Ji C, Jin L, Bi Y, Feng W, Li P, Shen S, Zhu D. Effects of Exenatide on metabolic changes, sexual hormones, inflammatory cytokines, adipokines, and weight change in a DHEA-treated rat model. Reprod Sci. 2016;23(9): 1242-9.

45. Hewitt SC, Deroo BJ, Hansen K, Collins J, Grissom S, Afshari CA, Korach KS. Estrogen receptor-dependent genomic responses in the uterus mirror the biphasic physiological response to estrogen. Mol Endocrinol. 2003;17:207083.

46. O'Brien JE, Peterson TJ, Tong MH, Lee EJ, Pfaff LE, Hewitt SC, Korach KS, Weiss J, Jameson JL. Estrogen-induced proliferation of uterine epithelial cells is independent of estrogen receptor alpha binding to classical estrogen response elements. J Biol Chem. 2006;281(36):26683-92.

47. Rencber SF, Ozbek SK, Eraldemir C, Sezer Z, Kum T, Ceylan S, Guzel E. Effect of resveratrol and metformin on ovarian reserve and ultrastructure in PCOS: an experimental study. J Ovarian Res. 2018:11:55.

48. Chen Z, Yuan Q, Xu G, Chen H, Lei H, Su J. Effects of Quercetin on proliferation and $\mathrm{H}_{2} \mathrm{O}_{2}$-induced apoptosis of intestinal porcine enterocyte cells. Molecules. 2018;23(8):2012.

49. Rajan RK, Kumar MSS, Balaji B. Soy isoflavones exert beneficial effects on letrozole-induced rat polycystic ovary syndrome (PCOS) model through anti-androgenic mechanism. Pharm Biol. 2017;55(1):242-51.

50. Ullah A, Jahan S, Razak S, Pirzada M, Ullah H, Almajwal A, Rauf N, Afsar T. Protective effects of GABA against metabolic and reproductive disturbances in letrozole induced polycystic ovarian syndrome in rats. J Ovarian Res. 2017;10:62.

51. Biapa NPC, Agbor GA, Oben JE, Ngogang JY. Phytochemical studies and antioxidant properties of four medicinal plants used in Cameroon. Afr J Tradit Complement Altern Med. 2007:4:495-500.

52. Konan Y, Witabouna KM, Bassirou B, Kagoyire K. Antioxidant activity and total phenolic content of nine plants from cote d'Ivoire (West Africa). J Appl Pharm Sci. 2014:4:36-41.

\section{Publisher's Note}

Springer Nature remains neutral with regard to jurisdictional claims in published maps and institutional affiliations.

Ready to submit your research? Choose BMC and benefit from:

- fast, convenient online submission

- thorough peer review by experienced researchers in your field

- rapid publication on acceptance

- support for research data, including large and complex data types

- gold Open Access which fosters wider collaboration and increased citations

- maximum visibility for your research: over $100 \mathrm{M}$ website views per year

At $\mathrm{BMC}$, research is always in progress.

Learn more biomedcentral.com/submissions 